\title{
PERGURUAN TINGGI ISLAM BERBASIS RISET MENYONGSONG BONUS DEMOGRAFI INDONESIA 2045
}

\author{
Muh. Duwana Saide \\ Nur Thahirah Umajjah \\ Institut Agama Islam (IAI) Al-Mawaddah Warrahmah Kolaka \\ Email: iranurthahira@gmail.com; duwanasaid@gmail.com
}

\begin{abstract}
The focus of the study in this paper is "The concept of developing PTKI through a researchbased education system in welcoming bonus demographic 2045". The conclusion of this paper is that the application of research-based learning systems can be an effective strategy in responding to the challenges of PTKI, especially in increasing the interest of the community to choose PTKI. In addition, this concept can also be used to produce students, outputs and PTKI alumni who excel in quality in order to prepare themselves to meet the Indonesian demographic bonus of 2045. The concept of developing research-based learning is done in several ways, namely: (1) in the research-based learning process, of course research results in accordance with the material material that will be taught, (2) conducting research activities in the learning process, (3) analyzing the results of the study comparatively with several other research results in the same study.
\end{abstract}

(Fokus kajian dalam makalah ini adalah Pengembangan PTKI melalui sistem pendidikan berbasis riset dalam menyambut bonus demografis 2045. Kesimpulan yang diperoleh adalah bahwa penerapan sistem pembelajaran berbasis riset dapat menjadi strategi yang efektif dalam menanggapi tantangan PTKI, terutama dalam meningkatkan minat masyarakat untuk memilih PTKI. Selain itu, konsep ini juga dapat digunakan untuk menghasilkan mahasiswa, output dan alumni PTKI yang unggul dalam kualitas dalam rangka mempersiapkan diri untuk memenuhi Indonesia bonus demografi 2045. Konsep pengembangan pembelajaran berbasis penelitian dilakukan dengan beberapa cara, yaitu: (1) dalam proses pembelajaran berbasis penelitian, tentu saja hasil penelitian sesuai dengan materi materi yang akan diajarkan, (2) melakukan kegiatan penelitian dalam proses pembelajaran, (3) menganalisis hasil penelitian secara komparatif dengan beberapa hasil penelitian lain dalam penelitian yang sama).

Keywords:, pembelajaran berbasis riset; Bonus Demografi Indonesia

\section{PENDAHULUAN}

Dalam meningkatkan kualitas-kualitas, PTKI membutuhkan strategi yang baik dalam hal kualitas staf pengajar, kurikulum, dan output dari komunitas akademis. Berdasarkan data dari dikte Kementerian Pendidikan dan Kebudayaan, ada sekitar 57 PTKIN dan 643 PTKIS tersebar di seluruh provinsi Indonesia. Seluruh PTKI berada di bawah naungan DIKTI Kementerian Agama Republik Indonesia. Selanjutnya meninjau, program studi yang ditawarkan dibagi menjadi dua kelompok besar, yaitu program studi ilmu-ilmu Islam seperti (pendidikan agama Islam, ilmu AlQur'an dan Tafsir, syariah), dan ilmu-ilmu 
umum seperti (fisika, obat-obatan, ekonomi). Survei membuktikan tantangan terberat universitas Islam adalah aliran persaingan dengan PTN. Oleh karena itu penulis tertarik untuk menguraikan konsep pendidikan berbasis penelitian sebagai strategi dan solusi dalam mengembangkan kualitas-kualitas dan menjawab tantangan PTKI di Indonesia dalam menyambut bonus demografi 2045.

Berkiblat pada Q.S At-Taubah ayat 122 yang artinya diuraikan sebagai berikut:

"Dan tidak sepatutnya orang-orang mukmin itu semuanya pergi kemedan perang, mengapa sebagian diantara mereka tidak pergi untuk memperdalam ilmu pengetahuan agama mereka dan untuk memberi peringatan kepada kaumnya apabila mereka telah kembali, agar mereka dapat menjaga dirinya".

Menurut Mustafa dalam Tafsir AlMaragi ayat ini menjelaskan aspek hukum yang menyangkut perjuangan Rasulullah SAW yaitu kedudukan mencari ilmu dan mendalami ilmu agama. Artinya bahwa salah satu bentuk perjuangan jihad fisabilillah adalah menuntut dan mendalami ilmu agama. Karena perjuangan menggunakan pedang hanyalah sebuah benteng pertahanan da'wah agar tidak dipermainkan oleh orang-orang yang akan mengintimidasi Islam ${ }^{1}$.

1 Ahmad Mustafa Al-Maragi, Terjemah Tasir Al-Maragi Juz, 10-11-12(Semarang, CV.Toha Putra, 1992)
Oleh karena itu, jelas perintah dalam menuntut ilmu agama merupakan salah satu bentuk jihad fisabilillahi. Sebab dengan memperdalam ilmu agama, maka akan meningkatkan keimanan dan ketaqwaan, serta menambah keyakinan atas kebesaran ALLAH SWT melalui ayat-ayat semesta. Bahkan, lebih lanjut meninjau sejarah peradaban Islam sahabat-sahabat nabi Muhammad SAW selain menjabat pada struktur pemerintahan, beliau juga sangat memperdalam ilmu agama. Sehingga, pada masa bani Umayyah dan Abbasiyah hadirlah ulama besar seperti, Imam Syafi'i ,Imam Abu Hanifah, Imam Maliki, Imam Ahmad bin Hanbal dan beberapa ulama lainnya.

Hukum menuntut ilmu dalam agama Islam adalah sifatnya "Fardhu Kifayah" dan "Fardhu "Ain" tergantung pada pentingnya ilmu tersebut. Hukum menuntut ilmu merupakan fardhu 'Ain jika ilmu itu menyangkut ibadah secara individual kepada ALLAH SWT misalnya shalat, puasa, dan lain sebagainya. Sementara hukum menuntut ilmu fardhu kifayah yaitu untuk ilmu yang sifatnya universal sepeti ilmu kedokteran, fisika, astronomi dan lain sebagainya. Dari uraian di atas jelas bahwa sangat diperlukan wadah dan strategi dalam pengembangan ilmu pengetahuan, baik ilmu agama Islam maupun ilmu yang sifatnya universal. 


\section{Al-Hikmah: Jurnal Dakwah, Volume 12, Nomor I, Tahun 2018 \\ [P. 117-130]}

Sebab perihal menuntut ilmu merupakan tanggungjawab bersama.

Salah satu wadah pengembangan ilmu agama Islam dan ilmu yang bersifat universal secara formal adalah PTKI baik yang berstatus negeri maupun swasta. Perguruan tinggi Islam merupakan lembaga pendidikan tinggi yang diselenggarakan oleh pemerintah maupun masyarakat yang bertujuan untuk menghasilkan ahli-ahli agama Islam yang bermutu serta bermanfaat bagi masyarakat tentunya dalam pengembangan ilmu agama, teknologi, dan kebudayaan. Sebab generasi yang terbentuk diharapkan memiliki kemampuan akademik, pengetahuan agama, dan tentunya output akhir dari proses ini adalah kemampuan mengabdi kepada keluarga, agama, masyarakat, dan negara.

Berdasarkan data diktis.kemenag.go.id. tercatat sekitar 57 PTKIN dan 643 PTKIS yang tersebar di seluruh wilayah provinsi Indonesia ${ }^{2}$. Keseluruhan PTKI tersebut berada di dalam naungan DIKTI Kementrian Agama Republik Indonesia. Lebih lanjut meninjau, program studi yang ditawarkan di bagi atas dua kelompok besar yaitu program studi ilmu-ilmu keIslaman seperti (pendidikan agama Islam, ilmu Al Qur'an dan Tafsir, syariah), dan ilmu-ilmu umum seperti (fisika, kedokte-

${ }^{2}$ http://diktis.kemenag.go.id/rankingptai/tbl_ptaisprovinsi.php. ran, ekonomi). Hal ini menunjukkan bahwa wadah pengembangan ilmu pengetahuan yang terintegrasi dengan pendidikan agama Islam di negara Indonesia telah cukup memadai. Sehingga, sudah sewajarnya PTKI menjadi piliha utama para generasi muda dalam melanjutkan jenjang pendidikannnya. Sebab PTKI tidak hanya menyediakan wadah keilmuan yang bersifat sains dan sosial, namun juga memberikan bekal ilmu keagamaan sebagai pondasi dasar dalam mengarungi kehidupan. Tetapi faktanya dibalik itu semua, ada banyak hal yang menjadi tantangan PTKI itu sendiri.

Survey membuktikan tantangan terberat perguruan tinggi Islam adalah arus persaingan dengan PTN. Hal ini tergambar pada data tahun 2007, Pusat Data dan Analisa Tempo pernah menyelenggarakan survei tentang persepsi masyarakat terhadap perguruan tinggi di Indonesia. Hasilnya, dari "top of mind" PTS, hanya Universitas Islam Indonesia (UII) yang masuk urutan ke-8 PTS terfavorit. Sebaliknya, tidak satupun PTAIN baik dari UIN, IAIN ataupun STAIN yang masuk "top of mind" terfavorit. Selanjutnya peringkat perguruan tinggi di Indonesia, sebagaimana dirilis oleh majalah "Globe Asia" edisi Februari 2008, dari kategori PTAIS, hanya Univesitas Muhammadiyah Malang (UMM) yang berhasil masuk 
peringkat ke-7 PTS terbaik di Indonesia. Untuk PTAIN belum satupun yang berhasil masuk dalam kelompok 10 PTN terbaik versi majalah ini. Sehingga, dalam menghadapi tantangan tersebut perlu sebuah strategi dalam pengembangan dan peningkatan mutu PTKI itu sendiri baik dari segi kualitas tenaga pendidik, kurikulum, dan output civitas akademika.

Oleh karena itu penulis tertarik untuk menguraikan konsep pendidikan berbasis riset sebagai strategi dan solusi dalam pengembangan kualitas mutu dan menjawab tantangan PTKI di Indonesia dalam menyongsong bonus demografi 2045. Konsep pendidikan berbasis riset pada PTKI adalah sebuah konsep dimana mahasiswa dalam mengkonstruksi ilmu pengetahuan yang akan diperoleh, itu melalui analisis riset hasil penelitian yang telah ada serta kegiatan perkuliahan dalam bentuk kegiatan riset seperti, analisis hasil riset penelitian yang telah ada, melakukan eksperimen, pengumpulan data, menganalisis data, dan melakukan evaluasi dari hasil riset. Adapun fokus kajian masalah pada tulisan ini yaitu "Konsep pengembangan PTKI melalui sistem pendidikan berbasis riset dalam menyongsong bonus demografi 2045".

\section{PEMBAHASAN}

Sebagai langkah awal mari meninjau kembali sejarah peradaban Islam pada masa puncak kejayaan Islam. Sejarah mencatat puncak kejayaan Islam terletak pada masa Bani Abbasiyah. Namun, sebelum masa Bani Abbasiyah, pada masa pemerintahan Bani Umayyah telah terdapat pola pendidikan pengkajian kitab secara kritis dan melakukan riset tersendiri yang dilakukan oleh para ahli. Hal ini digambarkan oleh Oliver Leaman dalam Suherdiman mengungkapkan bahwa:

“....pada masa peradaban agung [wujud] di Andalus, siapapun di Eropa yang ingin mengetahui sesuatu yang ilmiyah ia harus pergi ke Andalus. Di waktu itu banyak sekali problem dalam literatur Latin yang masih belum terselesaikan, dan jika seseorang pergi ke Andalus maka sekembalinya dari sana ia tiba-tiba mampu menyelesaikan masalah-masalah itu. Jadi Islam di Spanyol mempunyai reputasi selama ratusan tahun dan menduduki puncak tertinggi dalam pengetahuan filsafat, sains, tehnik dan matematika. Ia mirip seperti posisi Amerika saat ini, dimana beberapa universitas penting berada ${ }^{3,}$.

Menurut Sunanto Pada masa Bani Umayyah juga telah dilakukan kajian riset ilmiah, analisis penerjemahan dari kitab yunani ke dalam bahasa arab, serta kajian dan pengembangan ilmu dalam bidang

Budi Suherdiman Januardi, Jejak kegemilangan Islam dalam pentas sejarah dunia http://dudung.net, Dikutip pada tanggal 30 September 2011. 
sains ${ }^{4}$. Hal ini terurai dalam sejarah bahwa cucu Muawiyah Khalid Ibn Yazid sangat tertarik pada ilmu kimia dan kedokteran sehingga ia menyediakan sebahagian hartanya untuk diberikan kepada para sarjana yunani kuno yang melakukan penerjemahan buku kimia dan kedokteran kedalam bahasa arab. Lebih dari itu, untuk mengembagkan riset keilmuan khususnya dalam bidang kimia dan kedokteran, maka di dirikanlah sebuah lembaga yaitu "Bamaristan" Lembaga ini merupakan tempat studi riset kedokteran, tempat berobat dan merawat orang sakit. Selain itu, sistem pendidikan berbasis riset juga telah dilakukan di masa Bani Umayyah pada pemerintahan Umar Bin Abdul Aziz dengan metode "rihlah". Dimana pada metode ini, para ulama mencari hadits pada orang-orang yang dianggap mengetahuinya di berbagai tempat.

Selanjutnya, sistem pendidikan pada masa keemasan Islam yaitu pada masa Bani Abbasiyah. Pada masa dinasti ini terjadi puncak perluasan wilayah yaitu menguasai hampir 3/4 bahagian dunia, dan berkuasa selama 550 tahun atau 5 1/2 abad. Selain itu, di masa ini pula puncak

\footnotetext{
4 Musyrifah Sunanto, Sejarah Islam Klasik Perkembangan Ilmu Pengetahuan Islam, (Jakarta:Kencana, 2004), hlm. 41-42

5 Mahmud Yunus, Sejarah Pendidikan Islam, (Jakarta: Hidakarya Agung, 1992), hlm. 33
}

kejayaan ilmu pengetahuan dalam sejarah sepanjang peradaban Islam.

Dalam perkembangan keilmuan keislaman, kita mengenal 4 imam mazhab besar, yaitu; Imam Abu Hanifah (700-767 M), Imam Malik (713-795 M), Imam Ahmad ibn Hambal (780-855 M), dan Imam Syafi'i (767-820 M). Mereka semua hidup pada masa pemerintahan Abbasiyah. Selain itu, ada juga beberapa ulama besar yang sangat popular dalam mengumpulkan hadits seperti; al Musnad oleh Ahmad bin Hambal (241 H/885 M). Pengumpulan enam kitab yang dikenal al Kutub as Sittah yang dipelopori oleh Bukhari (256 H/870 M), Muslim (261 H/875 M), Abu Daud (275 H/888 M), at Tirmidzi (279 H/892 M), an Nasa'i (303 H/915 M), dan Ibnu Majah (273 H/886 M).

Menurut Hasan Abd. Ali, pada periode ini lembaga pendidikan yang menjadi tempat menuntut ilmu bukan hanya pada lingkungan keluarga, melainkan masjid dan kuttaab, Istana khalifah, rumah-rumah para pangeran, menteri, dan ulama, kedai-kedai, saudagar buku, salonsalon kesustraan, ribat, rumah sakit, alBimaristan, observatorium dan tempattempat experiment ilmiah serta Daar alHikmah, Bait al-Hikmah, dan Daar al-Ilmi ataupun Daar al-Kutub. Pendapat serupa di utarakan oleh Zuhairini dengan mengelompokkan lembaga-lembaga pendidikan 
Islam seperti Kuttaab, pendidikan rendah di Istana, toko-toko buku, rumah para ulama (ahli ilmu pengetahuan), badi'ah, rumah sakit, perpustakaan, dan masjid, sebagai lembaga pendidikan Islam yang bercorak nonformal. Sedangkan lembaga pendidikan formalnya adalah madrasah ${ }^{6}$.

Lebih lanjut meninjau, pada masa pemerintahan Daulah Bani Abbasiyah tidak jauh berbeda dengan Daulah Bani Umayyah, metode pengajaran yang digunakan dapat dikelompokkan menjadi tiga macam, yaitu:

1. Metode lisan dapat berupa dikte, ceramah, qira'ah, dan diskusi. Dikte (imla) adalah metode penyampaian pengetahuan yang dianggap baik dan aman karena dengan imla ini peserta didik mempunyai catatan yang akan membantunya ketika ia lupa. Ceramah (al-sama') adalah guru menjelaskan isi suatu buku dengan hafalan, sedangkan peserta didik mendengarkannya. Qira'ah biasanya metode ini digunakan untuk belajar membaca. Diskusi merupakan metode yang khas pada masa ini.

2. Metode menghafal merupakan ciri khas pendidikan pada masa daulah Abbasiyah. Peserta didik-peserta didik harus membaca secara berulang-ulang pelajarannya hingga pelajaran tersebut

${ }^{6}$ Suwito \& Fauzan. 2008. Sejarah Sosial Pendidikan Islam. Jakarta: Kencana Prenada media Group. hlm 100 . dihafalnya. Sehingga dalam proses selanjutnya, peserta didik harus mengkontekstualisasikan pelajaran yang telah dihafalnya.

3. Metode tulisan dapat dikatakan sebagai pengkopian buku-buku ulama. Dalam pengkopian terjadi proses intektualisasi hingga tingkat penguasaan ilmu peserta didik semakin tinggi, karena dalam pengkopian tidak semata-mata menulis saja dan melakukan telaah terhadap buku tersebut.

Sehingga, secara garis besar kemajuan pada Daulah Bani Abbasiyah ini ditentukan oleh beberapa upaya yang telah dilakukan, yaitu:

a. Adanya asimilasi antara bangsa Arab dengan beberapa bangsa lain yang telah mengalami perkembangan ilmu pengetahuan terlebih dahuluPada periode ini, bangsa-bangsa non Arab banyak yang masuk Islam, sehingga asimilasi berlangsung secara efesien dan efektif.

b. Gerakan terjemahan secara besarbesaran yang terbagi dalam tiga fase. Fase pertama pada masa khalifah alManshur hingga Harun ar-Rasyid. Pada fase ini banyak di terjemahkan adalah karya-karya dalam bidang astronomi dan manthiq. Fase kedua mulai pada masa khalifah al-Ma'mun hingga tahun 300 H. Buku-buku yang banyak diterjemahkan adalah dalam bidang 
filsafat dan kedokteran seperti buku logika karangan aristoteles dan geometri karya Euclid. Fase ketiga berlangsung setelah tahun $300 \mathrm{H}$, terutama setelah adanya pembuatan kertas. Bidang-bidang ilmu yang diterjemahkan semakin luas. Namun, titik berat dari gerakan ini adalah, para ilmuan tidak hanya melakukan penerjemahan, melainkan melakukan kritik dan pengembangan terhadap hasil kajian terjemahan dari kitab yunani kuno.

c. Aktivitas kreatif karya-karya yang sifatnya orisinil. Setelah dilakukannya gerakan penerjemahan besar-besaran, selanjutnya dilakukan kreatifitas karya orisinil dengan berbagai riset sesuai bidang kajian ilmu masing-masing ahli. Sehingga pada masa ini lahir beberapa tokoh utama misalnya dalam bidang kedokteran Ali Ibn Sahl Rabban alThabari, Ali Ibn Al abbas, dalam bidang filsafat muncul peneliti muslim Al kindi dengan sistem pemikirannya yang menggabungkan antara Aristoteles dan Plato, Al Farabi dengan sistem filsafatnya yang menggabungkan Platonisme, Aristotelianisme, dan Mistisisme, sedangkan Ibnu Sina mampu menyelaraskan antara pemikiran philo dengan ajaran Islam. Perkembangan pada bidang ilmiah memperkenalkan tradisi riset objektif, yang dikembang- kan oleh bapak kimia bangsa arab yaitu Jabir Ibn Hayyan. Sementara kajian histografi dilakukan dengan riset kebudayaan, tradisi biografi, dan narasi.

Berdasarkan uraian di atas, maka dapat disimpulkan bahwa pada dasarnya sebuah peradaban maju karena satu konsep, yaitu "Revolusi dan Cara Berfikir". Oleh karena itu, penggiringan konsep keterampilan berpikir tingkat tinggi atau yang dikenal dengan "Higher Order Thinking Skills" terus menerus dilakukan, tidak terkecuali di negara Indonesia. Hal ini terlihat pada perkembangan kurikulum yang saat ini sampai pada konsep berpikir "Saintifik". Dimana peserta didik mulai dari tingkat PAUD sampai pada SMA/MA Se-Derajat dituntut aktif dalam proses pembelajaran, mulai dari mengamati, bertanya, memberikan hipotesis, melakukan eksperimen, mengambil kesimpualn, dan mengevaluasi hasil eksperimen. Semua rangkaian proses pembelajaran tersebut adalah rangkaian sistem pembelajaran berbasis riset dalam kapasitas sederhana.

Oleh karena itu, sudah sewajarnya jika sistem pendidikan pada setiap proses pembelajaran PTKI diupayakan berbasis riset. Sebab melalui riset mahasiswa pada PTKI mampu mengasah dan mengembangkan keterampilan berpikir tingkat 
tinggi yang dimiliknya dan tentunya akan mendapatkan pengalaman belajar yang lebih menantang. Lebih dari pada itu, ouput dari PTKI berbasis riset mampu berpikir kritis, sistematis, sehingga dapat berasaing dalam menciptakan sebuah karya.

Konsep universitas sebagai lembaga riset muncul pada abad ke-19 di Jerman, di saat Revolusi Industri mulai menguasai dunia dan di era ledakan ide-ide baru. Munculnya ide-ide dan teknologi baru tersebut membutuhkan penelitian empiris di laboratorium untuk menguji keabsahannya agar dapat dikembangkan lebih luas. Keunggulan aspek penelitian dibanding pengajaran ditunjukkan pada tipe universitas versi Humboldtian yang menekankan bahwa perjalanan mengejar ilmu pengetahuan selayaknya perjalanan perusahaan. Aspek yang dapat dilihat dari universitas modern adalah adanya ketentuan pendanaan dari masyarakat dan pemerintah untuk mendukung penelitian ${ }^{7}$. Selanjutnya akan di uraikan beberapa universitas berbasis riset di dunia yang mampu membuat revolusi luar biasa.

Sebuah universitas sains dan teknologi di hongkong HKUST adalah universitas berbasis riset yang sangat berkembang pesat. Terbukti dengan

\footnotetext{
${ }^{7}$ Philip G. Altbach, Jamil Salmi, The Road to Academic Excellence, (Jakarta, Salemba Humanika, 2011).
}

keluaran outputnya yang mampu bersaing dalam dunia kerja. Lebih dari pada itu beberapa prestasi sebagai salah satu universitas terbaik dalam survey internasional sering kali diraih oleh universitas tersebut misalnya peringkat 39 dalam 100 universitas terbaik di bidang teknik dan teknologi serta komputer sains (peringkat 1 di "Greater China") pada tahun 2010 dan (e) peringkat 52-57 dalam 100 universitas terbaik di dunia dalam bidang ilmu sosial (peringkat 1 di "Greater China") pada tahun 2010.

Faktor keberhasilan HKUST adalah adanya rekruitmen dalam memperoeh ilmuan dan tenaga pengajar yang berbakat khususnya ilmuan dari cina yang pernah belajar di kampus terbaik misal di Amerika. Namun lebih dari pada itu, HKUST dalam pengembangannya juga sangat mementingkan kualitas pembelajaran berbasis riset, dan tentunya di dukung oleh pihak pemerintah dari segi anggaran dan, suntikan dana rutin dalam jangka waktu per tiga tahun dari University Grants Committee dan dana penelitian dari Research Grants Council yang baru saja didirikan.

Selanjutnya sebuah universitas riset swasta kelas dunia di pingiiran yaitu universitas sains dan teknologi Pohang (POSTECH) Republik Korea Selatan. Keunikan POSTECH yaitu kemampu- 
annya mencapai status kelas dunia hanya dalam tahap dua Dekade saja. Lebih menarik lagi, sebab universitas ini terletak di dearah pinggiran kota pesisir menengah disebelah tenggara semenanjung Korea. Bahkan telah dipertimbangkan sangat sulit untuk menarik pengajar yang berkualitas di daerah ini, begitupun dengan mahasiswa. Bahkan di awal pendiriannya mendapatkan banyak rintangan, salah satunya POSCO yang merupakan donator utama merasa skpetis apakah mampu membiayai universitas ini sampai universiats ini mampu membiayai dirinya sendiri.

POSTECH membangun reputasi nasional dan internasionalnya hanya dalam dua dekade lebih, dengan secara strategis fokus pada sains dan teknologi, bertahan dengan bentuk universitas berbasis riset yang kecil, dan mengundang ilmuwan yang dihormati secara internasional. Sejak tahun 1997, universitas secara konsisten berada di jajaran tiga besar dalam daftar peringkat universitas domestik; pada tahun 1998, dipilih menjadi "universitas sains dan teknologi" terbaik di Asia oleh AsiaWeek (1999); dan pada tahun 2010, berperingkat 28 dalam Peringkat Universitas Dunia dari Times Higher Education (2010). POSTECH saat ini sedang berusaha untuk menjadi 20 besar universitas dunia dalam 10 tahun mendatang.
Sekali lagi, keberhasilan POSTECH menjadi universitas kelas dunia tidak terlepas dari dukungan berbagai pihak termasuk pemerintah dari segi financial. Hal ini terbukti dari data Pemikir Korea 21 dimulai pada tahun 1999 dan akan ada sampai 2012, memberikan dukungan finansial kepada mahasiswa pascasarjana dalam proyek riset. Pada tahap pertama, yang berakhir pada tahun 2007, pemerintah mengalirkan US $\$ 1,3$ miliar kepada 564 tim riset di seluruh negeri. Tahap kedua, yang dimulai pada tahun 2008 memiliki US\$2 miliar disiapkan untuk 568 tim riset dari 74 universitas. Proyek Universitas Kelas Dunia, yang dimulai pada tahun 2008, adalah program subsidi dari pemerintah Korea yang bermaksud untuk membuat program akademik baru pada bidang-bidang yang meningkatkan pertumbuhan baru dan untuk meningkatkan kerja sama penelitian dan pengajaran internasional dengan mengundang ilmuwan terkemuka dari seluruh dunia. Pemerintah akan menginvestasikan 825 juta Dolar AS dalam program ini selama 2008-2012 (MEST 2008).

Pembelajaran berbasis riset (PBR) merupakan salah satu metode studentcentered learning (SCL) yang mengintegrasikan riset di dalam proses pembelajaran. PBR bersifat multifaset yang 
mengacu kepada berbagai macam metode pembelajaran. PBR memberi peluang/ kesempatan kepada mahasiswa untuk mencari informasi, menyusun hipotesis, mengumpulkan data, menganalisis data, dan membuat kesimpulan atas data yang sudah tersusun; dalam aktivitas ini berlaku pembelajaran dengan pendekatan "lear-

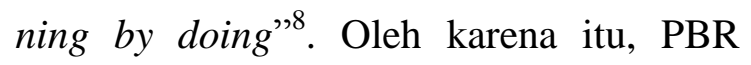
membuka peluang bagi pengembangan metode pembelajaran, antara lain:

1) Pembaharuan pembelajaran (pengayaan kurikulum) dengan mengintegrasikan hasil riset;

2) Partisipasi aktif mahasiswa di dalam pelaksanaan riset;

3) Pembelajaran dengan menggunakan instrumen riset, dan;

4) Pengembangan konteks riset secara inklusif (mahasiswa mempelajari prosedur dan hasil riset untuk memahami selu-beluk sintesis).

Berikut beberapa strategi dalam memadukan pembelajaran dan riset yang secara empirik dikembangkan:

a) Memperkaya bahan ajar dengan hasil penelitian dosen. Pada proses pembelajaran ini hasil penelitian dosen digunakan untuk memperkaya bahan ajar. Dosen dapat memaparkan hasil penelitiannya sebagai contohnyata dalam

8 Universitas Gadjah Mada. (Pedoman Umum Pembelajaran Berbasis Riset; Yogyakarta, 2010) perkuliahan, yang diharapkan dapat berfungsi membantu peserta didik.

b) Memahami ide, konsep, dan teori penelitian. Dalam kegiatan ini nilai, etika, dan praktik penelitian yang sesuai dengan bidang ilmu yang diajarkan dapat disampaikan untuk memberikan inspirasi kepada mahasiswa.

Pembelajaran berbasis riset merupakan salah satu metode yang mengintegrasikan riset di dalam proses pembelajaran. Beberapa model pembelajaran berbasis riset antara lain:

(1) Memperluas bahan ajar dengan hasil penelitian dosen.

(2) Memanfaatkan penelitian mutakhir dan melacak sejarah ditemukannya perkembangan mutakhir tersebut.

(3) Melakukan kegiatan pembelajaran dengan isu penelitian kontemporer .

(4) Memberikan materi metodologi penelitian di dalam proses pembelajaran.

(5) Memformulasikan proses pembelajaran dengan melibatkan mahasiswa dalam kegiatan penelitian

Proses pembelajaran berbasis riset telah di laksanakan di beberapa universitas terkemuka di Indonesia, di antaranya UGM, ITB, dan UI. Proses pembelajaran ini juga telah diuji cobakan di beberapa PTKI diantaranya tergambar pada jurnal 
penelitian yang dilakukan oleh Indra Mulyaningsih mahasiswa IAIN Syekh Nurjati, dimana proses pembelajaran berbasis riset diterapkan pada mata kuliah bahasa Indonesia, dengan sistem pengulasan artikel dan jurnal ilmuiah pada setiap pertemuan mata kuliah tersebut. Hasilnya menunjukkan pembelajaran tersebut efektif di gunakan selama proses perkuliahan.

Penelitian serupa juga dilakukan oleh Ahmad Nizar Rangkuti seorang mahasiswa pendidikan matematika IAIN Padangsidimpuan. Hasil penelitiannya menujukkan bahwa budaya melakukan riset dapat dijadikan sebagai salah satu indikator keberhasilan suatu universitas berbasis riset. Pembelajaran berbasis riset merupakan metode pembelajaran yang menggunakan pembelajaran autentik, pemecahan masalah, pembelajaran kooperatif, pembelajaran kontekstual, dan pendekatan inquiri yang dipandu oleh filsafat konstruktivisme. Pembelajaran berbasis riset ini dapat mengubah fokus pembelajaran dari penghafalan konsep-konsep dan fakta-fakta ke dalam belajar berdasar inkuiri. Pembelajaran berbasis riset dibangun berdasarkan pada sintesis beberapa teori belajar yang telah berkembang sebelumnya. Teori belajar yang dimaksudkan adalah teori behaveorisme, teori kognitivisme, dan teori konstruktivisme. Pembelajaran berbasis riset dapat memberi kontribusi terhadap pertumbuhan keterampilan mahasiswa dalam melakukan penelitian.

Oleh karen itu dapat disimpulkan bahwa proses pembelajaran berbasis riset di PTKI merupakan sistem pembelajaran yang berlandaskan pada teori belajar konstruktivisme. Dimana mahasiswa PTKI di tuntut untuk mengkonstruk pengetahuan berdasarkan pengalaman, baik dengan melakukan sebuah riset penelitian eksperimen, maupun kajian terhadap risetriset ilmiah yang telah ada. Proses pembelajaran ini menggunakan sistem pembelajaran berbasis riset dapat dilakukan dengan beberapa strategi yaitu: (1) dalam proses pembelajaran berbasis riset tentunya mengakji hasil riset sesuai dengan bahan materi yang akan di ajarkan, (2) melakukan aktivitas penelitian dalam proses pembelajarannya, (3) menganalisis hasil riset secara komparatif dengan beberapa hasil riset yang lain dalam kajian yang sama. Lebih lanjut, pembelajaran berbasis riset bertujuan untuk menciptakan proses pembelajaran yang mengarah pada aktifitas analisis, sintesis, pengembangan wawasan dan evaluasi serta meningkatkan kemampuan mahasiswa dan dosen dalam hal asimilasi dan aplikasi pengetahuan.

Dari uraian di atas jelas bahwa perguruan tinggi berbasis riset sangat memberikan peluang besar dalam mencip- 
takan generasi yang mampu bersaing dalam dunia kerja. Sebab sistem pembelajarannya berasal dari hasil temuan, baik temuan terdahulu maupun hasil karya orisinil yang ditemukan olehnya. Oleh karena itu, sudah selayaknya jika PTKI dalam model pembelajaran harus mengalami perubahan dengan menerapkan sistem pembelajaran berbasis riset demi menciptakan output civitas akademika ilmuan muslim yang taat dalam beragama, berdaya saing global, dan tidak lupa akan pengabdian kepada keluarga, masyarakat, dan negara.

Saat ini mahasiswa PTKI yang nantinya akan menjadi alumni kampus tersebut, dalam tahap menyongsong Bonus Demografi 2045. Dimana pada saat itu, Indonesia berada dalam kondisi jumlah penduduk yang melunjak dan lapangan kerja sangat terbatas. Sehingga, kreatifitas masing-masing penduduk akan menjadi modal utama dalam bertahan di dunia kerja. Olehnya itu, dengan diterapkannya model pembelajaran berbasis riset di PTKI diharapkan mampu membina mahasiswa sejak dini dalam berpikir kritis serta melakukan inovasi, sehingga nantinya mereka tidak hanya menjadi tenaga kerja, tapi menyiapkan lapangan kerja.

Tentunya jika pembelajaran berbasis riset diterapkan, maka hal utama yang harus diperhatikan, yaitu penempatan mata kuliah yang berhubungan erat dengan penelitian, seperti metodologi penelitian, statistika, evaluasi, seyogyana di tempatkan disemester awal. Sebab mata kuliah tersebut adalah mata kuliah yang mendukung proses pembelajaran berabsis riset. Karena, kenyataan dilapangan, hamper semua PTKI pada setiap program studinya menempatkan mata kuliah tersebut di semester akhir dengan landasan tubtutan kajian karya ilmiah sebagai tugas akhir (skripsi, thesis, disertasi). Dengan dilaksanakannya model pembelajaran berbasis riset ini akan memberikan manfaat bagi mahasiswa, dosen dan tentunya regulasi pengembangan mutu PTKI yang lebih baik.

Namun sangat disadari dari berbagai kelebihan proses pembelajaran berbasis riset, tentunya terdapat beberapa tantangan PTKI dalam menerapkan sistem pembelajaran tersebut, diantaranya:

1. Kecukupan dari segi financial, jika proses pembelajaran berbasis riset tersebut pada outputnya mengahasilkan sebuah produk

2. Diperlukannya tenaga professional dalam menerapkan sistem pembelajaran tersebut

3. Perlu ditingkatkannya budaya literasi dikalangan mahasiswa dan tenaga pendidik 
4. Pihak kampus perlu menyediakan fasislitas yang dibutuhkan untuk mengaplikasikan proses pembelajaran tersebut

5. Membutuhkan proses yang cukup lama untuk melatih mahasiswa dalam membudayakan pembelajaran berbasis riset

\section{KESIMPULAN}

Berdasarkan kajian masalah di atas, maka dapat diberikan kesimpulan bahwa penerapan sistem pembelajaran berbasis riset dapat menjadi strategi yang efektif dalam menjawab tantangan PTKI khususnya dalam meningkatkan minat masyarakat untuk memilih PTKI. Selain itu, konsep ini juga dapat digunakan untuk menghasilkan mahasiswa, output dan alumni PTKI yang unggul dalam kualitas guna menyongsong bonus demografi tahun 2045. Konsep pengembangan pembelajaran berbasis riset dilakukan dengan beberapa cara yaitu: (1) dalam proses pembelajaran berbasis riset tentunya mengakji hasil riset sesuai dengan bahan materi yang akan di ajarkan, (2) melakukan aktivitas penelitian dalam proses pembelajarannya, (3) menganalisis hasil riset secara komparatif dengan beberapa hasil riset yang lain dalam kajian yang sama. Hal yang perlu diperhatikan untuk menerapkan pembelajaran berbasis riset tersebut yaitu penempatan mata kuliah yang berhubungan erat dengan penelitian, seperti metodologi penelitian, statistika, evaluasi, seyogyana di tempatkan di semester awal.

\section{DAFTAR PUSTAKA}

Ahmad Mustafa Al-Maragi. 1992. Terjemah Tasir Al-Maragi Juz 1011-12, Semarang: CV Toha Putra

Budi Suherdiman Januardi, Jejak kegemilangan Islam dalam pentas sejarah dunia http://dudung.net, Dikutip pada tanggal 30 September 2011.

http://diktis.kemenag.go.id/rankingptai/tbl _ptaisprovinsi.php.

Yunus Mahmud. 1992, Sejarah Pendidikan Islam, Jakarta: Hidakarya Agung.

Musyrifah Sunanto. 2004, Sejarah Islam Klasik Perkembangan Ilmu Pengetahuan Islam, Jakarta: Kencana.

Philip G. Altbach, Jamil Salmi. 2011, The Road to Academic Excellence, Jakarta: Salemba Humanika.

Suwito \& Fauzan. 2008. Sejarah Sosial Pendidikan Islam. Jakarta: Kencana Prenada media Group

Universitas Gadjah Mada. 2010, Pedoman Umum Pembelajaran Berbasis Riset; Yogyakarta. 
Muh. Duwana Saide dan Nur Thahirah Umajjah:

Perguruan Tinggi Islam Berbasis Riset Menyongsong Bonus Demografi Indonesia 2045 